\title{
New Thoughts on Canadian Research
}

The Science Council of Canada has taken the unusual step of publishing the record of its opinion of, mostly dissent from, the report of the Macdonald Committee which, in May this year, advocated a far-reaching reorganization of the mechanism for government support of scientific and industrial research in Canada. The Macdonald Committee was originally appointed by the Science Council to make proposals for the future organization of Canadian research. The underlying tone of its report (sce Nature, 222, 1024; 1969) was decentralizing -it argued that there should be a new research council to support research in the humanities and that the responsibility of the National Research Council for laboratorics should be separated from its responsibility for supporting university research by means of research grants. The Macdonald Committee also took a leaf from the earlier report of the National Science Board in the United States by asking that the federal government, through the rescarch councils, should accept more directly its responsibility for graduate education in Canada.

The critique of the Macdonald Report, now issued as Report No. 5 of the Science Council of Canada (University Research and the Federal Government, 75c), takes a more conservative line, possibly not without reason. Thus it argues that the National Research Council should remain undivided as at present, but it is also anxious that the grant giving research councils should be encouraged to provide "broad guidance" in the direction taken by university rescarch. The Science Council would also like to see a greater proportion of the federal support for research and development provided by the mission oriented departments of government.

The rate of growth of expenditure on academic science by the federal government has been striking. Since 1960-61, expenditure has risen from $\$ 14.4$ million to $\$ 119$ million. The National Research Council has consistently provided about a half of the total federal expenditure $(\$ 65$ million in $1969-70)$. The Medical Research Council is the next largest source of support-roughly a quarter of the federal academic science budget is provided this way. The Canada Council (not to be confused with the Science Council) is at present one of the principal sources of support for the humanitics.

In its commentary on the Macdonald Report, the Science Council says that the council fully acknowledges the need for continued growth both in the supply of money and in the encouragement of graduate education, but it emphasizes the importance of nonuniversity establishments. It also takes the point emphasized by the Macdonald Committee that, under the present arrangements, some areas of legitimate research are almost entirely neglected-business ad. ministration, education and music are some of those mentioned-and argues that the existing machinery for support should be strengthened to include these fields. The Science Council does not, however, follow the Macdonald Committee in its suggestion that there should be a new rescarch council for the humanities.
One of the points which the Science Council singles out is that the available research funds are not fairly distributed across the face of Canada. It thus commends the scheme, originally suggested by the Macdonald Committee, that there should be a system of "strategic development grants" aimed at developing centres of excellence in places such as the Atlantic provinces and French Canada where university development is comparatively laggard.

The Science Council, indeed, goes further than Macdonald in advocating a system of grants for university research which looks very much like a close analogy with the proposals of the National Science Board in the United States-in other words, there would be individual project grants for the support of what is called "little science", programme grants for supporting teams of people, major grants to get interdisciplinary projects or "big science" launched, special grants for projects related to the development of Canada or of the university system and general purpose grants to help new developments.

On the choice of rosearch projects, the Science Council takes the view that the research councils should be active, not passive as Macdonald would have had them, and that "within the university sector itself, it will be increasingly necessary to specialize and to concentrate effort in order to achieve the standards of excellence which we desire". On the Macdonald Committee's proposal that grant giving agencies should payoverhead costs, the Science Council demurs - it does not want to be tied down by a general recommendation although it does accept the point that universities and no other agency must be responsible for academic salaries. On computing equipment and facilities, it looks forward to a system under which costs will be properly assessed and relatcd to the projects which use them. In practice, this will mean fewer lump sum grants for computers and more willingness to see computing costs included in applications for ordinary research grants.

The Science Council also rciterates its views, expressed on several occasions in the past few years, that "a major failing in Canadian science has been the performance of too much basic research remote from the training of new scientists and the performance of too much applicd research far from the point of innovation".

In this spirit it urges that government departments should be more willing to work either with universities or with industry in launching new programmes. It also recommends that the interests of the mission oriented agencies should be backed up by the grant giving agencies with longer term interests in mind. On the tricky question of whether the National Research Council should be divided, the Science Council argues that there is at present a natural cvolution of events that will bring about a de facto separation of the responsibility for laboratories and for giving grants "in the not too distant future", but it also says that there would be administrative advantages in keeping both functions within the same framework. 